九州大学学術情報リポジトリ

Kyushu University Institutional Repository

\title{
A REVISIONAL STUDY ON THE GENUS MICROPISTUS THtiRY AND ITS ALLIES (COLEOPTERA, BUPRESTIDAE)
}

Kurosawa, Yoshihiko

Department of Zoology, National Science Museum

https://doi.org/10.5109/2527

出版情報 : ESAKIA. Special Issue 1, pp.57-64, 1990-04-20. Entomological Laboratory, Faculty of Agriculture, Kyushu University

バージョン：

権利関係 : 


\title{
A REVISIONAL STUDY ON THE GENUS MICROPISTUS THÊRY AND ITS ALLIES (COLEOPTERA, BUPRESTIDAE)
}

\author{
Y OSHIHIKO KUROSAWA \\ Department of Zoology, National Science Museum, Tokyo \\ 3-23-1, Hyakunin-cho, shinjuku, Tokyo, 160 Japan
}

\begin{abstract}
The genus Micropistus ThERY, 1922, contains three species from the Indochinese Peninsula and one from the Malayan Peninsula. A new species, M.hirashimai, from eastern Thailand is described, and a new subtribe, Callopistina, which includes three Indomalayan genera including Micropistus, Callopistus and Kolleria, and three African genera including Steraspis, Pygichueta and Chrysaspina, is established.
\end{abstract}

In 1982, the author described two new species of the genus Micropistus THERY, 1922, viz., dilatatus from Malaya and toyamai from northern Thailand. Since then, the author was able to examine the type specimen of Philocteanus igneiceps E. SAUNDERS, 1872, preserved in the British Museum (Natural History), and was convinced that toyamui is nothing but a synonym of igneiceps. Recent studies on a large lot of materials brought from the Indochinese Peninsula made the author believe that the centre of dispersal of this genus was in the peninsula. There he recognized three species, including one new to science. He also found the existence of numerical mimicry among several species of the genera Chrysochroa, Micropistus and Iridotaenia similar to that reported in 1982 among the Malayan Buprestidae.

\section{Genus Micropistus ThERY, 1922}

Micropistus THÊRY, 1922, Annls. Soc. ent. Belg., 62: 203.

Type species : Micropistus microcephalus THÊRY, 1922 (Nouvelle Guinée) (by monotypy).

Body cuneiform or subcuneiform, and attenuate posteriorly.

Head moderately small ; width including eyes not broader than the width of anterior margin of pronotum and slightly narrower than a half the width of the base of pronotum; frons slightly excavated between eyes, with median line distinctly grooved ; eyes slightly converging above, moderate, not swollen out laterally, with interior margin oblique and slightly sinuate anteriorly ; clypeal suture absent ; clypeus broad and transverse, with anterior margin bilobed ; antennae short and compact, eleven-segmented, serrate from the third segment, which is longer than twice the second, with the serrate segments from the fourth to tenth as long as or wider than long, apical eleventh one distinctly separated from the tenth, and sensory pores diffused on both sides of each serrate segment.

Pronotum transverse, subtrapezoidal, strongly attenuate anteriorly, with median line of disc smooth or impunctate, or inconspicuously carinate; marginal carinae sharply defined in the posterior two-thirds and strongly curved down inferiorly ; anterior angles abased and ill-defined ; disc more or 
less impressed and constricted along anterior margin; posterior margin bisinuate, about twice as long as or slightly narrower than the width of anterior margin. Scutellum dorsally invisible.

Elytra irregularly punctato-striate, with interstices obsoletely costate and minutely and sparsely punctate; sides irregularly dentato-serrate near apices, which are separately unidentate or spinose.

Body beneath somewhat navicular and produced or subgibbose at the middle of the first ventral segment of abdomen in lateral aspect ; prosternum subtruncate anteriorly and more or less impressed along the anterior margin, with the process deplanate, longitudinally but broadly and obsoletely carinate at the middle; first ventral segment of abdomen swollen or subgibbose between posterior coxae; last ventral segment of abdomen emarginate (male) or rounded (female) at apex.

Legs rather short and slender, with anterior and middle tibiae slightly curved basally, and basal segment of each tarsus more or less longer than the second.

Range : Burma, Indochinese Peninsula, Malay Peninsula.
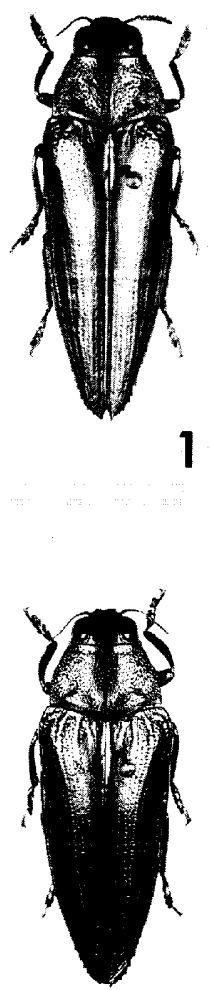

5
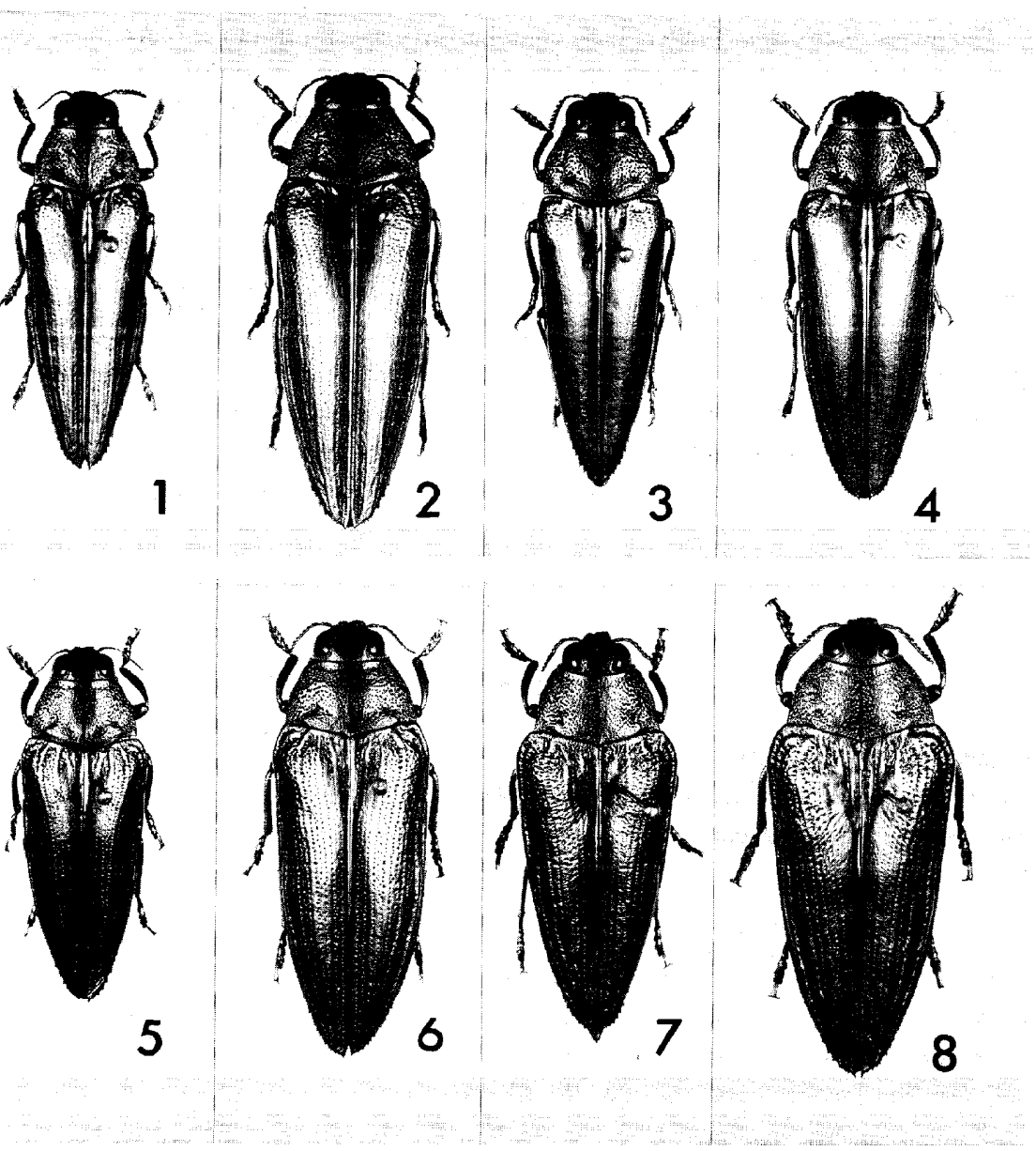

Figs. 1-8. Dorsal views of four Micropistus species.-1. Micropistus microcephalus THERY, 1922, ơ;2. same species, $q$; 3. M. hirashimai Y. Kurosawa, nov., $\sigma^{7} ; 4$. same species, $ᄋ$; 5. M. igneiceps (E. SAunders, 1872), $\sigma^{7}$; 6. same species, $q$; 7. M. dilatatus Y. KurosawA, 1982, $0^{7}$; 8. same species, $q$. 
Based upon a new species, microcephalus, from "Nouvelle Guinée", this genus was established by A. THERY in 1922. Although microcephalus was regarded in 1927 by THERY himself as a synonym of Burmese Philocteanus igneiceps E. SAUnders, 1872, the genus remains availablle for igneiceps E. SAUNDERS. The locality of microcephalus, "Nouvelle Guinée", has been revised by Théry himself to Indochina. Believing THERY's opinion and also believing that the specimens from Laos presented from A. Baudon as true igneiceps, the author described a new species, M. toyamai, from northern Thailand. A close examination of a syntype preserved in the collection of the British Museum (Natural History) has proved that toyamai is nothing but a synonym of igneiceps and microcephalus THÉRY, 1922, is specifically independent from igneiceps. However, there is another species from eastern Thailand, which the author is going to describe as a new species in the following lines, together with a key to the four species.

Key to the Species of the Genus Micropistus THERY, 1922

1. Body slenderer, with humeri less prominent ; pronotum bicolorous, partially tinged with coppery, with the anterior two-thirds of sides and anterior angles more or less margined with coppery red ; sutural part of elytra impunctate and smooth ; first ventral segment of abdomen slightly produced between posterior coxae, but not gibbose

- Body robuster, rather deplanate, with humeri more prominent ; pronotum concolorously greenish ; sutural part of elytra finely but sparsely punctured ; first ventral segment of abdomen subgibbose between posterior coxae

2. Reddish margin of pronotum indistinct ; elytra aurora1 red with greenish shimmer,
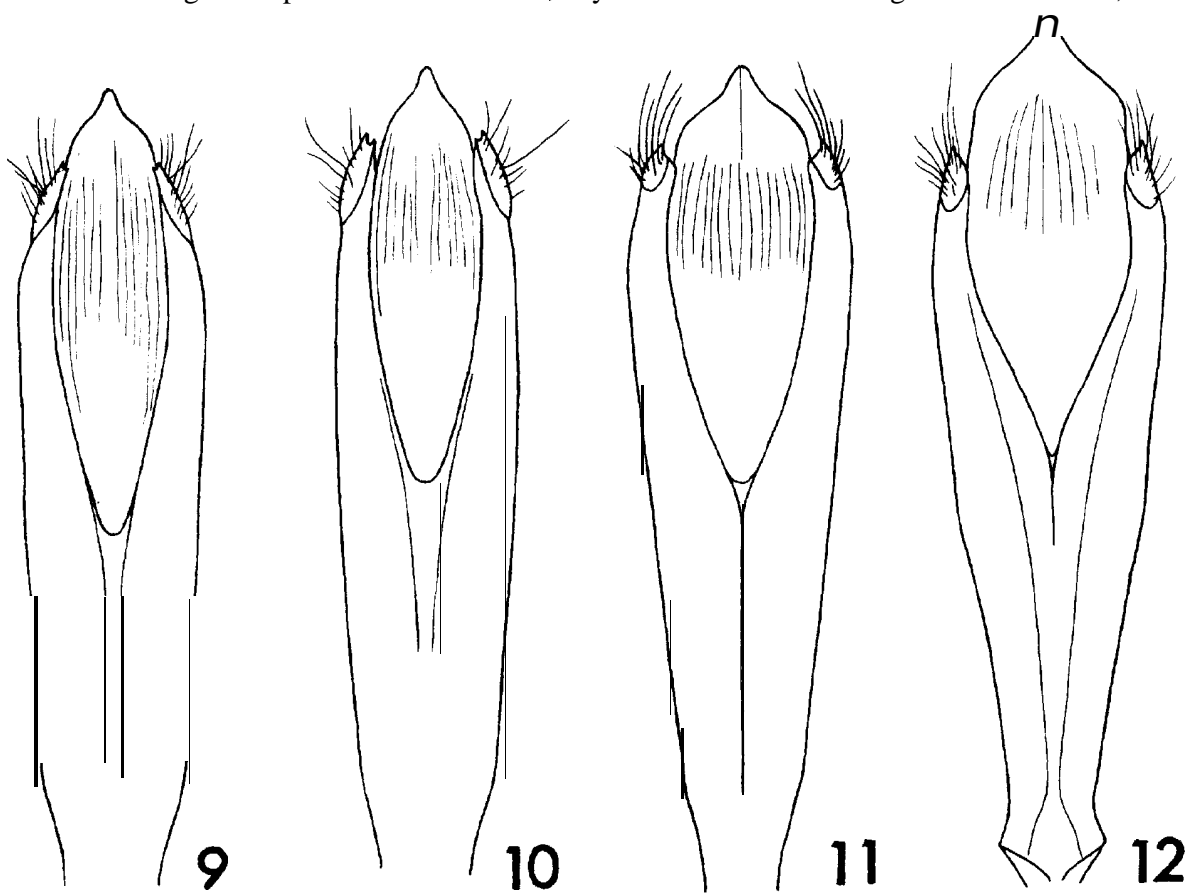

Figs. 9-12. The dorsal views of male genital apparatus.-9. Micropistus hirashimai Y. KuRosawA, nov.; 10. M.microcephalus THERY, $1922 ; 11$. M. igneiceps (E. SAUNDERS, 1872) ; 12. M. dilatatus Y. Kunosawa, 1982. 
changing bronzy green in some aspects; elytral punctuation finer and smooth

hirashimai sp. nov.

Reddish margin of pronotum distinct ; elytra greenish, margined with golden or golden red; elytral punctuation stronger, coarser and denser microcephalus THERY, 1922

Body subovate, attenuate posteriorly in the male, with humeri less prominent ; body beneath reddish golden green; elytral punctuation weaker, with the intervals not rugose

igneiceps E. SAUNDERS, 1872

Body subtriangular, attenuate posteriorly, with humeri prominent ; body beneath cupreopurpureous ; elytral punctuation stronger, with intervals somewhat rugose except for post-scutellar part

dilatatus Y. KuROSAWA, 1982

\section{Micropistus hirashimai $Y$. KURosawa, sp. nov.}

(Figs. 3, 4, 9)

Body slender, attenuate posteriorly, though the attenuation is stronger in the male than in the female ; above lustrous ; head including mouth parts and vertex bright coppery red ; pronotum cupreoaureous, with the sides, anterior margin, and posterior angles greenish or bluish; elytra auroral red with greenish shimmer, changing green in some aspects, with apex tinged with bronzy red; body beneath bright golden red with greenish shimmer; antennae blackish with an aneneous tinge ; legs golden green, with tarsi darker, slightly tinged with coppery.

Head small ; frons broadly excavated between eyes, edged and subcarinate along eye on each side, broader in male than in female, coarsely and sparsely punctate by larger punctures anteriorly and laterally, punctured by fine punctures all over the surface; median groove narrow but deep; vertex not grooved at middle; anterior margin of clypeus arcuately emarginate between lateral lobes; antennae short and compact, with the third segment slender, slightly longer than twice the length of the second, and the fourth slightly but distinctly longer than the fifth.

Pronotum transverse, about 1.6 times as wide as long, and widest at the base; sides feebly sinuate just before each basal angle, feebly swollen or subangulate at the middle, then obliquely attenuate to anterior angles ; anterior margin somewhat arcuately emarginate, without median lobe ; anterior angles acute and slightly produced in dorsal aspect, abased and ill-defined in lateral aspect ; posterior margin bisinuate, with the median lobe obtusely angulate at the ante-scutellar part; posterior angles somewhat acute and slightly produced latero-posteriorly ; disc obsoletely and longitudinally impressed, posteriorly touching the basal margin ; surface punctate coarsely and confluently at the sides, sparsely at the middle, but microscopically punctured on intervals of larger punctures. Scutellum dorsally invisible.

Elytra convex, about 2.2 times as long as wide, about 4 times as long as pronotum, and widest at humeri, which are slightly broader than the base of pronotum ; sides obliquely narrowed from humeri to apices and strongly dentato-serrate near apices, which are sharply but separately dentate ; marginal carinae reflexed and carinate in anterior three-fifths and bisinuate in basal half; disc more smooth than in other species, with four obsolete costae on each elytron, first and second from suture obsolete, impunctate, but almost not elevated, lateral two costae slightly elevated, running from just behind humerus to near apex, but conjuncted with each other just before apex ; surface with three kinds of punctures, larger coarse ones arranged in lines suturally but confluent in the humeral part, a few smaller ones sparsely scattered on intervals of larger lined ones, and minute microscopic ones scattered over intervals of larger ones.

Body beneath lustrous, with two kinds of punctures, finer and smaller ones and small ones, and 
covered with inconspicuous hairs. Prosternum convex ; anterior margin subtruncate, reflexed ; prosternal process broad, deplanate, arcuately constricted at the middle, with a broad, impunctate median carina between two longitudinal rows of irregular punctures. Meso- and metasterna flattened and sparsely scattered with fine punctures at the middle. First ventral segment of abdomen projected posteriorly between posterior coxae, but not gibbose. Apex of last ventral segment semicircularly but broadly and obtusely emarginate between two large lobes (male) or rounded (female) at apex.

Length : 25.2-32.3 mm ; width : $8.2-10.5 \mathrm{~mm}$.

HoLOTYPE $\left(0^{\top}\right)$, allotype ( + ) and paratypes :60 ơ 29 , Khon Kaen, E. Thailand, vii. 1987. All the type-specimens excluding several paratypes are preserved in the National Science Museum, Tokyo.

Distribution : E. Thailand.

This species, standing closely near M.microcephalus THERY, 1922, from the northern Indochinese Peninsula, differs from the latter in the points mentioned in the key and in the proportion of the lengths of antennal segments. This may be a relict isolated in the inland dry area of the Indochinese Peninsula.

\section{M icropistus microcephalus THERY, 1922}

(Figs. 1, 2, 10)

Micropistus microcephalus THÉRY, 1922, Annls. Soc. ent. Belg., 62: 203 (Nouvelle Guinée).

Philocteanus igneiceps : KeRREMANs, 1908, Monogr. Bupr., $3: 201$ (Birmanie) (rev. nov.).

Micropistus igneiceps : THÉRY, 1927, Annls. Soc. ent. Fr., $96: 252$; Y. Kurosawa, 1982, Bull, natn. Sci. Mus. Tokyo, (A), $8: 180$.

Body above metallic or lustrous green or golden green, with head including vertex flamy red or cupreous, pronotum dark bronzy green on disc, margined with coppery red on anterior two-thirds of the sides and anterior angles, and elytra margined with golden red and more or less reddish at apices ; body beneath greenish golden to reddish golden, stronger in reddish tinge on prosternal process and central gibbosity of first ventral segment of abdomen between posterior coxae ; antennae blackish, with a slight aeneous tinge; legs metallic green above and golden beneath.

Body more deplanate though slightly than in hirashimai; punctuation of pronotum and elytra stronger and denser than that of hirashimai, and somewhat sparser than that of igneiceps ; third antennal segment slightly shorter than three times the second, while about three times as long in hirashimai, and distinctly shorter than three times in igneiceps ; pronotum about 1.65 times as wide as long ; elytra about 2.3 times as long as wide ; prosternal process broader and less constricted than that of hirashimai ; apex of the last ventral segment of abdomen subtriangularly emarginate between two lobes in male.

Length : 22.8-32.0 mm ; width : 7.0-10.2 $\mathrm{mm}$.

Spectmens examtned : $10^{0} 2$ 2 9 , Paksé, Laos, 15. vi. 1965, A. P. Baudon lgt. ; 10 19, Vientiane,

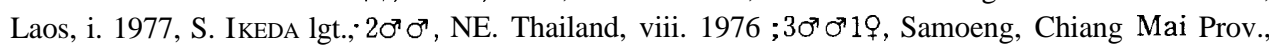

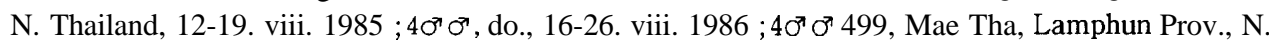
Thailand, 28. vii.-31. viii. 1986 ;19, Fang, Chiang Mai Prov., N. Thailand, 26. viii. 1985 ;19, Chiang Dao, Chiang Mai Prov., N. Thailand, vii. 1988.

Distribution : Laos, N. Thailand.

The most frequent species in northern Thailand and northern Laos. It may be expected also from northern Vietnam, eastern Burma, and southern Yunnan of China. 
A short description by Ch. Kerremans in 1908 agrees well with this species.

Micropistus igneiceps (E. SAUnders, 1872)

(Figs. 5, 6, 11)

Philocteanusigneiceps E. SAUnders, 1872, Trans. ent. Soc. London, 1872 : 242 (Burma).

Micropistus igneiceps : ThERY, 1927, Annls. Soc. ent. Fr., 96: 252.

Micropistus toyamai Y. KuRosawa, 1982, Bull. natn. Sci. Mus., Tokyo, (A), $8: 199$, fig. (Chiang Dao,

N. Thailand) (syn. nov.).

Body above entirely metallic green, with exceptions of frons, clypeus, mouth parts flamy cupreous, and vertex golden green to golden, but the green is sometimes tinged with cyaneous ; body beneath greenish golden, with the median parts, especially in prosternal process and central gibbosity of first ventral segment of abdomen, strongly tinged with reddish coppery ; antennae dark green to dark aeneous, with the parts of undersurface diffusing sensory organs blackish.

Body rather robust, deplanate, somewhat subtriangular in male with humeri prominent ; antennae short and compact, with the third segment about 2.5 times as long as the second, and about 1.5 times as long as the fourth, which is about as long as or slightly longer than the fifth ; punctuation of head coarser and stronger than in the preceding two species ; pronotum more transverse than in the preceding two, about 1.7-1.8 times as wide as long, and widest at base; sides oblique, slightly swollen or subangulate just behind the middle ; anterior margin slightly reflexed and impunctate ; posterior margin bisinuate, with the median lobe obtusely angulate and produced at the middle ; posterior angles subrectangular or slightly acute and slightly produced latero-posteriorly ; disc transversely but rather obsoletely depressed from scutellar part to basal angles; surface rather densely punctate, but the punctuation becomes sparser towards the middle, denser and conflunt towards the sides.

Elytra broader and more deplanate than in the preceding two ; about 2.1-2.2 times as long as wide, about 4.2 times as long as pronotum, and widest at humeri, which are prominent from the base of pronotum ; sides gradually narrowed to apices, which are separately unidentate, but the apical dentation is shorter and less acute than in the preceding two ; marginal carinae bisinuate at humeri and the part of posterior coxae, and then reflexed to the dentate part ; disc subdeplanate ; surface punctato-striate, 4-costate, but the discal costae are inconspicuous, the third costa from shoulder to apex, and the submarginal costa entire, and distinctly elevated.

Prosternal process deplanate, with the median elevation broad and obsolete, and the sides slightly constricted. First ventral segment of abdomen subgibbose between posterior coxae. Last ventral segment of abdomen semicircularly or subtriangularly but broadly emarginate between two lobes at apex in male.

Length : 24.2-30.0 mm ; width : 8.2-10.0 mm.

Specimens eXAmined :19, Chiang Dao, Chiang Mai Prov., N. Thailand, 10. viii. 1980, K. Sugino lgt. (holotype of toyamui) ; 10 5ㅇ, Samoeng, Chiang Mai Prov., N. Thailand, 16. vi.-15. ix. $1986 ; 1$ ơ, Do., 25. viii. 1988 ;19, Wiang Pa Pao, Chiang Rai Prov., N. Thailand, 4. vii. 1988 ;19, Burma (syntype), in coll. British Mus. (Nat. Hist.).

Distribution : N. Thailand, E. Burma.

Not so frequent as microcephalus THËR, though these two species are found sympatrically in northern Thailand. This species stands closer to Malayan dilatatus Y. Kurosawa than to Indochinese hirashimai nov. and microcephalus THÊRY.

There is a problematic female specimen from Chiang Dao, Chiang Mai Province in northern 
Thailand (24. vi. 1979, W. SuzUKI lgt.), which has the body attenuate as in microcephalus, and the golden tinged elytra margined with golden red with fine discal punctuation as in microcephalus, but its pronotum is distisnctly broader, transverse and not margined as in igneiceps. Though these characteristics indicate that this specimen belongs to a fifth independent species in this genus, it is premature to describe it as a new species. It might be a hybrid between igneiceps and microcephalus.

\section{Micropistus dilatatus Y. Kurosawa, 1982}

(Figs. 7, 8, 12)

Micropistus dilatatus Y. Kurosawa, 1982, Bull. natn. Sci. Mus., Tokyo, (A), 8: 181 (Cameron Highlands, Malay Peninsula).

This species is characterized by its subtriangular body like some species of the genus Evides, the rugose punctuation on the elytra and the entirely cupreo-purpureous body beneath.

For exact description of this species, see the author's original description in 1982.

Length : 28.3-34.2 mm; width : 10.8-13.4 mm.

Specimens eXAmined : lb, Cameron Highlands, Malay Peninsula, 10. v. 1986 ;19, Do., v. 1976 (holotype) ;19, Do., v. 1977 (paratype).

Distribution : Malay Peninsula.

\section{Taxonomic Position of the Genus Micropistus ThERY in the Family Buprestidae.}

Because of the unique feature of the absence of scutellum, the genus Micropistus THERY, 1922, has formerly been placed in the tribe Chrysochroini of the subfamily Buprestinae, or in the subfamily Chrysochroinae. However, this character is so unstable that it cannot be regarded as a main character of a tribe or a subfamily. Together with several African and Indomalayan genera, Micropistus forms a small subtribe in the tribe Buprestini of the subfamily Buprestinae. Besides the characteristics of the structure of antennae and pronotum mentioned in the following lines, the body densely covered with yellowish powder in fresh examples as seen in tropical genera becomes an important feature for separating higher groups of the Buprestidae. For this reason, the tribe Chrysochroini with the body nude from the powder belongs to a group different from that to which the genus Micropistus belongs. This small buprestine subtribe including Micropistus is represented in Indomalayan area by the genus Callopistus H. DeYrolle, 1864, and in Africa by the genus Steraspis SOLIER, 1833.

\section{Subtribe Callopistina subtr. nov.}

Type genus : Callopistus H. DeYrolle, 1864.

Head small, about a half the width of pronotum ; pronotum constricted behind the anterior margin and impressed along the anterior margin ; antennae short and compact, and serrate from the third segment.

The following lndomalayan genera and African genera belong to this new subtribe. Callopistus H. Deyrolle, 1864, Micropistus ThÉry, 1922, and Kolleria Théry, 1925, from Indomalayan area and Steraspis Solier, 1833, Chrysaspina ThERY, 1930 and Pygichaeta OBEnBERger, 1920 from Africa.

The author is much indebted to Dr. Shun-Ichi UÉno of the National Science Museum, Tokyo, for his kind reading of the original manuscript, to Mr. Toshio Inomata of Tokyo, for his excellent 
photographs and to Mr. Masao TOyama of Nishinomiya, for his kind criticism to the present study. The author expresses his great gratitude to these entomologists.

\section{References}

Baudon, A., 1960. Contribution à l'étude des Buprestides du Laos. Bull.Soc. Sci. nat Laos, (1) : 64. - 1966. Catalogue commente des Buprestidae recoltes au Laos, 1. Mem. Soc.roy. Ent. Belg., 30 : 27-28.

Kerremans, Ch., 1903. Coleoptera, Serricomia, Buprestidae, 2. In Wytsman, M. P. (ed.), Gen. ins., fasc. 126: 53.

— 1908. Monographie des Buprestides, 3 : 193-252.

Kurosawa, Y., 1982. A remarkable convergence found in Malayan Buprestid beetles, with descriptions of two new species from Thailand and Hainan. Bull.natn. Sci. Mus., Tokyo, (A), 8: 180-182, 199, figs.

Obenberger, J., 1926. Buprestidae, 1. In Junk, W., \& S. Schenkling (eds.), Coleopt.Cat., 12 (84) :112113.

Saunders, E., 1872. Descriptions of twenty new species of Buprestidae. Trans. ent. Soc. London, $1872: 242$.

Théry, A., 1922. Études sur les Buprestides. Annls. Soc. ent. Belg., 62: 203-204.

— 1927. Études sur les Coléoptères Buprestides appartenant aux collections des grandes musées (1 ${ }^{\mathrm{er}}$ note: British Museum). Annls. Soc. ent. Fr., $96: 252$. 